\title{
TRANSITIVITY PROCESS AND IDEOLOGICAL CONSTRUCTION OF DONALD TRUMP'S SPEECHES
}

\author{
Nova Anggraini ${ }^{\bowtie}$, Alyssa Sahnaz, Elsa Lisanul Fathonah, M. Rizal Al Farisi, Murni Fidiyanti \\ UIN Sunan Ampel Surabaya \\ ఐnovaanggrn14@gmail.com
}

\begin{abstract}
This research is the collaborative study of Critical Discourse Analysis with the new grammar perspective of Halliday's Systemic Functional Linguistics Theory focusing on Transitivity System. It investigates the pattern of transitivity process that reveals the linguistic strategies as well as its ideological construction of Donald Trump's speeches in the $45^{\text {th }}$ United States presidential election. The writer mainly utilizes Fairclough's framework for CDA which consists of three stages of analysis consisting of description, interpretation, and explanation. Under descriptive-qualitative method, this research significantly gives an understanding about how transitivity processes can be used to reveal the ideology. As the result, Donald Trump uses variety language during his speeches. It is because he applies all the types of transitivity process proposed by M.A.K. Halliday which consists of six types: material, mental, relational, behavioral, verbal, and existential. The transitivity processes eventually reveal that Donald Trump attempts to construct democratic view during his speeches.
\end{abstract}

Keywords: critical discourse analysis; systemic functional linguistics; transitivity process; ideology

\section{INTRODUCTION}

In recent years, the discussions of grammar have moved from sentence-based perspective to more of a discourse-based perspective. The discussion of grammar from discourse-based perspective goes along with the theory of M.A.K. Halliday, the Systemic Functional Grammar which is also known as Systemic Functional Linguistics Theory (SFLT). Considering SFLT as a new perspective in grammar, it has attracted many researchers to conduct the research in this field. A number of researchers have explored SFLT in various data sources, such as, news (Zhang, 2013; Viscido, 2014), advertisement (Patpong, 2008), movie script (Fikmawati, 2012; Viana, 2013; Setiawan, 2015), student's writing (Kurdali, 2012; Nurohmah, 2013; Oliveira, 2015) and essay (Rollins, 2012).

As a part of SFLT, transitivity system is applied as the concern of this research. Several researchers have focused on investigating transitivity system in some settings with different forms of analysis, for instance: in academic setting which includes student's text book (Salsabil, 2014; Anggun, 2016; and Oriza, 2017); politic setting which news (Sidabutar, 2014; 
Ong'onda, 2016), and debate (Zhang, 2017). Those previous studies had captured all aspects in transitivity system. In the meantime, to create new findings of the current study the writer not only presents the analysis of transitivity process but also connects it with another subject, that is, Critical Discourse Analysis (CDA).

The term CDA is used to refer more specifically to the critical linguistic approach of scholars who find the larger discursive unit of text to be the basic unit of communication. This research specifically considers institutional, political, gender and media discourses (in the broadest sense) which testify to more or less overt relations of struggle and conflict (Wodak \& Meyer, 2001: 2). As the study of CDA, the writer intends to examine the ideological construction since ideology becomes one of the main terms in CDA. Ideology became an interesting topic for many previous critical discourse studies. It had been widely used by many researchers in different cases of analysis. Kaur, Arumugam, \& Yunus (2013), Khoiriyah (2016), and Nugrawidhanti (2016) analyzed the ideology in advertisement; Sipra \& Rashid (2013), Al-Haq \& Al-Sleibi (2015), and Mohammadi (2017) reveal the implied ideology behind the speech; Fauzan (2014) and Aslani (2016) examined the ideology that underlie the news. All of these studies employ three-dimensional model by Fairclough as their framework for the analysis. They carried out three stages of analysis consisting of textual analysis, processing analysis, and social analysis to investigate the ideology.

From the explanation above, the previous studies about ideological construction had tended to focus on using Fairclough's framework in usual way since they generally followed the stages of analysis. Therefore, in present analysis the researcher tries to analyze the ideology from an interesting way by inserting transitivity system in description stage. Transitivity system works for examining the linguistics feature of the text. In this case, description stage is limited on experiential values on type of process and participant since it is based on transitivity system. Later, the researcher chooses Donald Trump's speeches as data sources. There are three speeches to be analyzed, they are: Trump's Campaign speech in Charlotte, Inauguration speech, and Victory speech.

This study aims to explore Critical Discourse Analysis study with the new grammar perspective of Halliday's Systemic Functional Linguistics Theory focusing on the transitivity processes. This research significantly gives an understanding about how transitivity processes can be used to reveal the ideology as Critical Discourse Analysis study. Because this research combines CDA with transitivity processes, it means that this research explores more CDA as multidisciplinary which means that CDA can be combined with any sub-discipline theory (Wodak \& Meyer, 2001: 96). Moreover, transitivity process is the new theory because it is the 
development from sentence-based perspective (the traditional one) to more discourse-based perspective (SFLT).

\section{REVIEW OF LITERATURE}

\subsection{Halliday's Systemic Functional Linguistics Theory}

Systemic Functional Linguistics Theory is the development of grammar study from sentence-based perspective to more discourse-based perspective. Some of linguists have argued that the development of this theory is needed because the traditional explanations of grammar do not adequately capture grammatical selection in longer, real-world text (Paltridge, 2006: 127). Nazlia (2016: 12) explains that SFL is a theory which is introduced by M. A. K. Halliday, a professor of Linguistics from University of Sydney, Australia. Halliday adopted this theory from his teacher named J.R. Firth. Firth developed Malinowski's concept about context of situation and context of culture which is known as system structure theory. Then, Halliday developed this theory to be the theory of language in context which is known as Systemic Functional Grammar. Halliday's Systemic Functional Linguistic Theory (SFLT) is a theory which talks about language and functional grammar. It maintains a perspective on language that is grounded in how we actually use language to construct reality and enact social relationships. This theory claims that language is functional. Functional means that language, like other semiotic systems, is a systemic resource for making and exchanging meaning. A semantic system is organized into three main functional components, or "metafunctions". The three components are: ideational, interpersonal, and textual (Halliday \& Webster, 2009: 5). Ideational Function is a function of language that is used to represent human experiences. Ideational function is divided into two sub-functions, logical and experiential. Logical function views language as natural logic and it is realized by the clause complexity system, while experiential function views language as representation of human experiences and it is realized by the transitivity system. Interpersonal function is a function used to maintain human relationship, it is realized through system of mood. Textual function is used to organize human experiences in the text (message), it is realized through theme system.

\subsection{Transitivity System}

Transitivity system belongs to experiential metafunction. The experiential metafunction focuses on the clause level in which the clause is viewed as the representation of human experience in reality through some processes. The processes can represent about what is going on in reality: of doing, happening, feeling, or being. Thus, clause is the most significant unit 
in this case (Halliday, 1985: 101). In transitivity process there are three major components, they are participant (attend the circumstances and do the process), process (regarded as various actions), and circumtances (represent time, place, manner, cause, accompaniment, matter and role). Here, these three components always appear in each type of transitivity process.

\subsubsection{Types of Transitivity Process}

According to Halliday in his book An Introduction to Functional Grammar, there are six types of transitivity process (1985: 101-131).

\section{a.) Material Process: Process of Doing}

Material process is the process of 'doing'. It expresses the notion that some entity 'does' something which may be done 'to' some other entity. In the material process, there are two participants role, namely: Actor (the entity which 'does' something) and Goal (the entity which 'undergoes' the process). In this case, an Actor is obligatory while a Goal is optional in the clause. For example:

\begin{tabular}{|c|c|c|}
\hline The lion & caught & the tourist \\
\hline Actor & Process & Goal \\
\hline
\end{tabular}

\section{b.) Mental Process: Process of Sensing}

Mental process is the process which constitutes the three principal sub-types, they are: perception (seeing, hearing, etc.), affection (liking, fearing, etc.), and cognition (thinking, knowing, understanding, etc.). In the mental process, there are two participants, namely: Senser (the conscious being that is feeling, thinking, or seeing ) and Phenomenon (the entity which is 'sensed'- felt, thought or seen). Let's see the example below:

\begin{tabular}{|c|c|c|}
\hline I & believe & you \\
\hline Senser & Process: Cognition & Phenomenon \\
\hline
\end{tabular}

\section{c.) Relational process: Process of Being}

Relational process is the process of being. This process describes the relationship of one entity and another entity which is encoded through three types, namely:

1. Intensive ' $\mathrm{x}$ is a' (establishes a relationship of sameness between two entities)

2. Circumstantial ' $x$ is at a' (defines the entity in terms of location, time,manner)

3. Possessive ' $x$ has a' (indicates that one entity owns another)

Each of those comes in two modes, they are attributive and identifying. Attributive mode occurs when one entity is used to assign another. It has two participants named as carrier and 
attribute. Then, identifying mode occurs when one entity is used to identify another. It has two participants named as identified (token) and identifier (value). The three types and two modes create six possible classifications of relational processes that are set out in the following table:

\begin{tabular}{|c|c|c|}
\hline Type & (i) Attributive & (ii) Indentifying \\
\hline (1) intensive & Sarah is wise & $\begin{array}{c}\text { Tom is the leader } \\
\text { the leader is Tom }\end{array}$ \\
\hline (2) circumstantial & the fair is on a Tuesday & $\begin{array}{l}\text { tomorrow is the } 10^{\text {th }} \\
\text { the } 10^{\text {th }} \text { is tomorrow }\end{array}$ \\
\hline (3) possesive & Peter has a piano & $\begin{array}{l}\text { the piano is Peter's } \\
\text { Peter's is the piano }\end{array}$ \\
\hline
\end{tabular}

\section{d.) Behavioral Process: Process of Behaving}

Behavioral process is the process of physiological and psychological behavior. Grammatically they are intermediate between material and mental process. This means that behavioral process includes the action process but the action is done with consciousness, for example: breathing, dreaming, smiling, waving, laughing, coughing, watching, listening etc. The majority of behavioral process clauses have one participant that is called as Behaver (the agent who behaves). The example is as follows:

\begin{tabular}{|l|l|}
\hline Buff & neither laughs nor smiles \\
\hline Behaver & Process \\
\hline
\end{tabular}

\section{e.) Verbal Process: Process of Saying}

Verbal process is the process of saying. The participants of this process are: Sayer (participant who speaks), Receiver (the one to whom the verbalization is addressed), and Verbiage (a name for the verbalization itself). There is also one other type of verbal process, in which the Sayer is in sense acting verbally on another direct participant, with verbs such as: insult, praise, slander, abuse, and flatter. This other participant will be referred to as the Target. For example:

\begin{tabular}{|l|l|l|l|}
\hline \multicolumn{1}{|c|}{ She } & asked & \multicolumn{1}{c|}{ him } & a lot of questions \\
\hline Sayer & Process: vebal & Receiver & Verbiage \\
\hline
\end{tabular}

And also the example of target:

\begin{tabular}{|l|l|l|l|}
\hline I & 'm always praising & you & to my friends \\
\hline Sayer & Process: verbal & Target & Recipient \\
\hline
\end{tabular}




\section{f.) Existential Process: Process of Existing}

Existential process represents that something exists or happens. The clauses of this process typically have the verb be, or some other verb expressing existence, such as exist, arise, followed by a nominal group functioning as Existent. Existent is a thing which exists in the process, it is the only participant of this process. The existent may be a phenomenon of any kind, and is often, in fact, an event. For example:

\begin{tabular}{|l|l|l|}
\hline There & was & an old woman \\
\hline & Process & Existent: entity \\
\hline
\end{tabular}

\subsection{Critical Discourse Analysis}

Critical Linguistics (CL) or also known as Critical Discourse Analysis (CDA) is one of the approaches to discourse analysis which adopts a macroanalytical view of language. It means that the analysis of this study not only concern on the text itself (micro-analysis) but also involves the relation of the text with the context (macro-analysis). CDA research specifically considers how language works within institutional and political discourses (e.g. in education, organization, media, government), as well as specific discourses (around gender and class), in order to uncover overt or more often covert inequalities in social relationships (Litosseliti, 2010: 126).

According to Fairclough (1989: 26) in seeing language as discourse and social practice, one is committing oneself not just to analyzing texts, nor just to analyzing processes of production and interpretation, but to analyzing the relationship between texts, processes, and their social conditions. This notion produces what we call as the dimensions of discourse, contained of texts, interactions, and contexts. Corresponding to these dimensions of discourse, Fairlough relates them to the three stages analysis of Critical Discourse Analysis, namely: description (textual analysis), interpretation (processing analysis), and explanation (social analysis). The relation of three dimensions of discourse with the stages analysis of CDA can be seen clearly through the diagram below: 


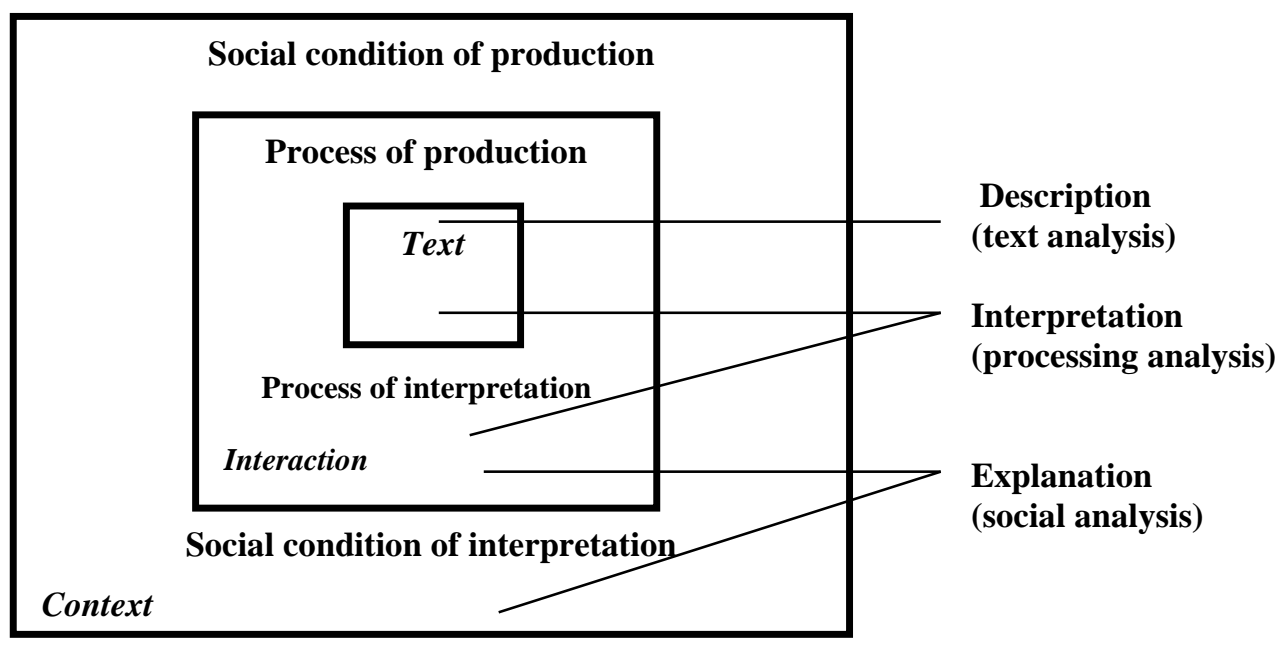

\subsection{Ideology}

Sargent (1981: 3) asserts that an ideology is a value or belief system that is accepted as fact or truth by some group. It is called as a 'system' because ideology refers to a belief that is organized. He adds that ideology is composed of sets of attitudes toward the various institutions and process of society. It provides the believer with a picture of the world both as it is and as it should be, and, in so doing. Here, the ideology which is shared by a group of people can emotionally affect people's attitude, it influences an individual or other groups of people to choose, act or do something.

\section{RESEARCH METHODS}

In this study, descriptive-qualitative method was considered as the most appropriate research design to be adopted. Ary (2010: 474) noted that descriptive qualitative inquiry dealt with data that were in the form of words or pictures rather than numbers and statistics, in this case the data itself were the text of speeches.

The data source for this study was the textual script of Donald Trump's speeches. The researcher specifically chose three speeches, they were: Campaign speech in Charlotte (26/10/2016), Victory speech (9/11/2016), and Inaugural speech (20/1/2017). Additionally, the data analysis for the present study were in the form of clauses taken from the textual script of Donald Trump's speeches.

The key instrument of this research was human. It referred to the researcher herself who had the role to collect and analyze the data. Moreover, there was also supporting instrument that helped the writer to conduct the research, such as, laptop and books. Those tools were used for searching and gathering the information, and also doing the analysis of the research.

In order to collect the data the researcher did some steps such as searching the video and its script, downloading the video and its script, reading the script and watching the video, and 
collecting the data in the form of clauses. After the data had been collected, the researcher analyzed the data by identifying the data, classifying the data into six types of transitivity process, analyzing the data, and drawing the conclusion.

\section{RESULTS AND DISCUSSIONS}

\subsection{Types of Transitivity Process Used in Donald Trump's Speeches}

From the three speeches used in present research, it is found that there are 708 clauses which contain transitivity processes. Those total numbers come from various types of transitivity process. The findings of transitivity process types appeared in all speeches are generally illustrated in the following chart.

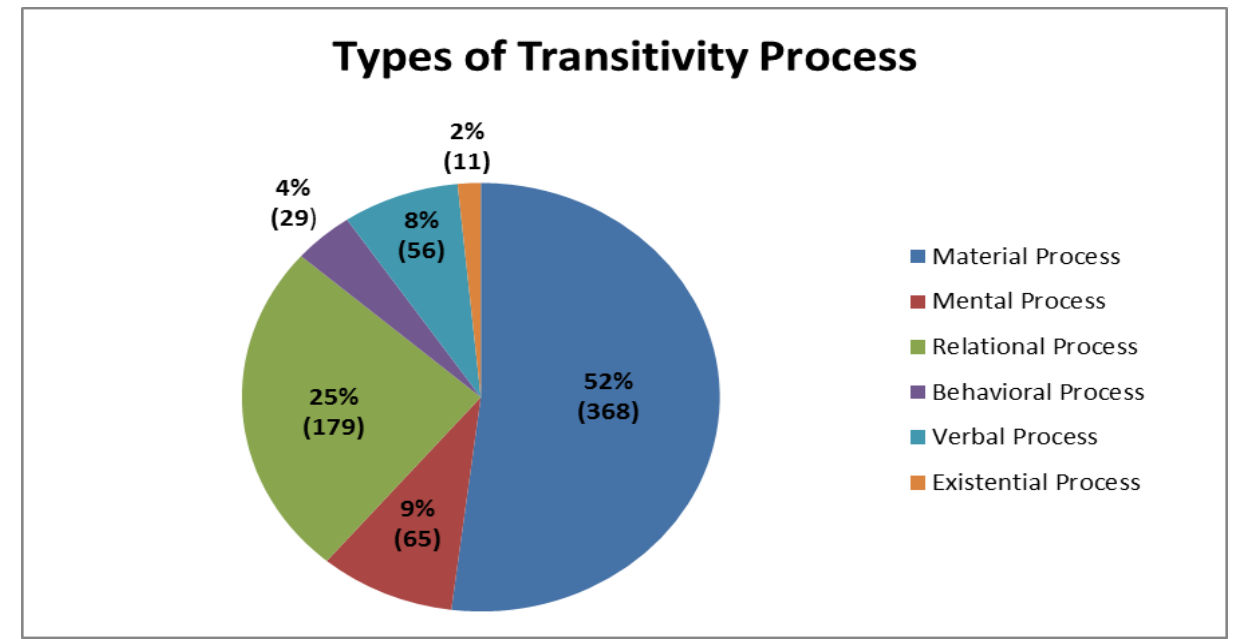

Figure 4.1: The Emergence of Transitivity Process Types in Donald Trump's Speeches

Meanwhile, the emergence of transitivity process types used in each speech is charted as follows.

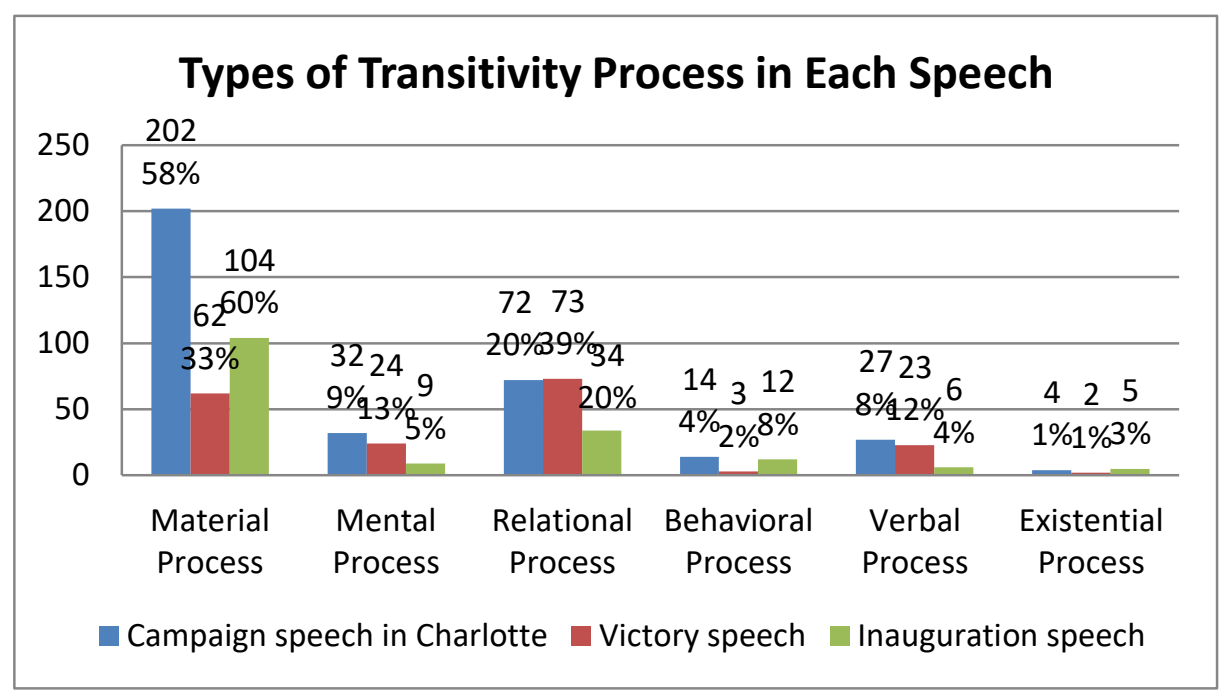

Figure 4.2: The Emergence of Transitivity Process Types in Each Donald Trump's Speech 


\subsection{Ideology of Donald Trump's Speeches}

This part presents Fairclough's framework for Critical Discourse Analysis that is used to reveal the implied ideology of Donald Trump's speeches. The framework itself follows three stages of analysis consisting of description, interpretation, and explanation.

\subsubsection{Description Stage}

In description stage, transitivity analysis is employed to serve the linguistics feature of the speeches.

\section{a.) Material Process}

Material process as the process of doing is mainly used for indicating Donald Trump's words for actions such as protect, determine, restore, make, put, unify, work, reform, rebuild, etc. His material clauses signal the actions that will be done for the future government. It is indicated by the use of modal will that is frequently uttered along with his action words. Material process becomes the most significant process in his campaign speech and inauguration speech. It reaches the highest percentage among the other processes that appear in these two speeches. This reflects that campaign and inauguration speeches are mainly delivered to state the actions. Meanwhile, in victory speech material process is regarded as one of the significant processes since it places the second level of emergence. Material clauses in the victory speech strengthen Donald Trump's statements about his future actions that have been delivered in the campaign speeches.

Donald Trump did not merely use material clauses to indicate his own actions. He also uttered material clauses to refer to Hillary Clinton as his opponent in the campaign. In this case, material processes were used to indicate Trump's inconsistency. It considers whether the speech occured before or after Donald Trump was elected as the president. In the campaign speech, delivered by Donald Trump before being elected as the president, material processes appeared tend to portray negative implication when it was directed to Hillary. As the evidence, the process indicating Hillary Clinton's actions were described as bad actions such as destroy, betray, sacrifice, and doesn't care. While, in the inauguration speech, delivered after being elected as the president, material processes used to describe Hillary Clinton's actions seem to have positive implication such as fought and has worked. Such inconsistency is regarded as his speech strategy to persuade the public. By presenting the bad actions of his opponent in his campaign speech, Trump tried to compare his actions and showed the betterment of his future actions so that he could attract people attention to support him.

\section{b.) Mental Process}


Mental process as the process of sensing is used by Donald Trump to express and also ask the people to see, hear, feel, and even think about what is going on in America. Mental process describes psychological actions which involve the process of perception such as see and hear; affection such as hurt, love, regret, and want; cognition such as learn, think, understand, remember, imagine, and know. The use of mental process in Trump's campaign and inauguration speeches varied since all the types of mental process were used by the speaker. Thus, mental process in those speeches represent Donald Trump's process of percieving, feeling, and thinking. On the other hand, in the victory speech not all types of mental process were used by Trump. They contained affection and cognition, while perception does not exist. Thus, mental process in the victory speech is used to represent Donald Trump's process of feeling and thinking.

\section{c.) Relational Process}

Relational processes as the process of being are applied to describe, define, identify, and even symbolize something related to America's circumstances. Through this process, Trump is able to portray America and its people's condition and also show how he unites himself with the Amerian people. This process is indicated by either to be such as is, are, was, were, have been or possession words such as has/have. In the data found, the types of relational process that appear in the three speeches are intensive and possessive. This implies that relational clauses in all of the speeches are mainly used by the speaker to assign or identify the sameness of two entities and ownership of something.

In addition, Donald Trump also used relational process to describe Hillary Clinton as his opponent in the election and Barack Obama as the previous president of United States. In his campaign speech, by using relational process Hillary Clinton was identified as a bad person such as the greatest liars and disaster. These processes have negative implication. While, in his inauguration speech the process tends to have positive implication since it is used to identify a positive characteristic of magnificent which belongs to Obama. This case infers that there is inconsistency in using transitivity process before and after he becomes a president. As in material process, this inconsistency is also considered as Trump's speech strategy. Trump describes his opponent as a bad person because he wanted to show that he was the best one to be the leader of the United States. Meanwhile, after winning the election he no longer uttered bad impression, he just needed to express his grateful feeling.

\section{d.) Behavioral Process}

Behavioral process as the process of behaving was encoded by Donald Trump to express and ask the people to act with their consciousness. In his campaign speech, behavioral clauses 
were mostly used by Donald Trump in imperative form. He used behavioral process to ask the people to do some actions dealing with the consciousness such as look and listen. On the other hand, in his victory and inauguration speeches, behavioral clauses were only occured to indicate Donald Trump's actions as the speaker. He used behavioral process to state his physical actions dealing with the consciousness such as look, listen, watch, wave, enjoy, ignore, etc.

\section{e.) Verbal Process}

Verbal process as the process of saying conveys Donald Trump's verbal actions which were directed to the American people. In his campaign speech, verbal clauses were not only used to indicate Donald Trump himself, but also used to indicate Hillary Clinton as his opponent in the campaign and President Obama as the incumbent president of the United States. Then in his victory speech, as the first speech conducted after being elected as the new president, verbal processes were mostly used by Donald Trump to thank to his family, friends, and the American people who supported him during the president election. They were not only used to indicate Donald Trump himself, but also used to indicate Hillary Clinton. In the inauguration speech, Donald Trump also used verbal process to thank to the people as the audiences in the speech. Different from his two previous speeches, verbal processes in this speech were only used to indicate Donald Trump himself.

\section{f.) Existential Process}

Existential process as the process of existing reflects America's condition related to the existence and absence of something. The data found shows that the emergence of existential process reaches the lowest percentage in all of the speeches. It is because this process becomes the most infrequent process produced in the three speeches. This means that the three speeches are rarely used to describe the existence or absence of something.

\subsubsection{Interpretation Stage}

In this section, the interpretation stage was made by relating the linguistics features of the text found from transitivity analysis to the interaction which produces the themes reflected from the speeches. Here are the themes found:

\section{a.) National Unity}

The unity of nation refers to the effort of unifying all the citizens to become one single unity, so that they feel the same feeling and also fight for the same vision and mission. Dealing with political speech, national unity usually becomes one of the main concepts that underlie the idea of the speaker. This also occurs in this study in which the unity of nation becomes the crucial theme of Donald Trump's speeches. It can be seen from all of the 
speeches used in the study. The concepts of national unity frequently appear in the speeches and are encoded through various types of transitivity process. Here are the examples:

We are one nation (data 38)

When one state hurts, we all hurt (data 25)

We are one country, one people and we will have together one great future (data 39)

To be one united nation (data 41), we must protect all of our people (data 1)

The examples above are Donald Trump's utterances in his Campaign speech in Charlotte. His utterances reflect the idea of national unity. By using relational process, Trump identifies himself with the citizen of American as one nation, one country, and one people which have the same one great future. He also used mental process of affection to express the feeling of "hurt" that should be felt together by the citizen as one nation. Moreover, Trump also strengthened his idea by giving material process for defining the action as one nation that is to protect all of the people. The concept of national unity also exists in his two other speeches below.

To all Republicans and Democrats and independents across this nation, I say it is time for us to come together as one united people (data 69)

The quotation above is the utterance of Donald Trump in victory speech. In this case, he tried to establish national unity by using verbal process in which he pointed all Republicans and Democrats and independents across the nation and said to them that it was time to come together as one united people. Later on, Donald Trump once again stated the concepts of national unity in his inauguration speech as it is quoted below.

We are one nation and their pain is our pain (data 51).

Their dreams are our dreams and their success will be our success (data 52).

We share one heart, one home, and one glorious destiny (data 20).

These quotations show that Donald Trump mentioned several times the concept of national unity by using relational processes. The use of relational process indicates that Trump and the American people are identified as one nation who have the same pain, dreams, and also success. Then, it is supported by material process that because they are one nation so they share one heart, one home, and one glorious destiny. In addition, the most apparent feature in reflecting national unity is the use of pronoun "we" in almost all of utterances in the three speeches. The use of first person plural "we" reflects togetherness as one unity. This means that Donald Trump's as the speaker unites himself with the American people and reflects no distance between the leader and his people during his speeches. Finally, it can be inferred that there is a consistency in constructing national unity since these concepts can be easily found in the three speeches of Donald Trump. 


\section{b.) Equality}

Equality is the state of being equal in status, right, and also opportunity. It considers no separations regarding different races, religions, backgrounds, and another social aspect. The concepts of equality spread in all of Donald Trump speeches. This means that he wanted to maintain a strong view toward his leadership that he would fight for the principle of equality for all the citizens of America. The term of equality are reflected through some types of transitivity process in his speeches. Here are the examples:

Every single citizen in our land has a right to live in safety (data 40)

I will not rest until children of every color in this country are fully included in the American

Dream (data 2). This is what I promise to African-Americans, Hispanic-Americans, and all Americans (data 42).

In my Administration, every American will be treated equally, protected equally, and honored equally (data 11)

The quotations above were uttered by Donald Trump in his Campaign speech in Charlotte. Those utterances implied the ideas of equality that were encoded through relational and material processes. In the case of relational processes, the words "has a right" and "this is what I promise" were used to describe the equality which belongs to "every single citizen" and "African-Americans". There are also material processes such as "will not rest" and" "will be treated" which were directed at the goals "children of every color" and "every Americans". The use of word "every" in many cases shows that Trump tried to signal the equality for all American people without any exception, especially in race. The topic of equality in race emerges since he used the words "every color" and "African-Americans" which implied that there was no different treatment between white people and black people who live in America. Then, the concepts of equality also appeared in two speeches after being elected as a president as in the data below.

It is a movement comprised of Americans from all races, religions, backgrounds, and beliefs (data 47)

that whether we are black or brown or white (data 54)

we all bleed the same red blood of patriots (data 61)

We all enjoy the same glorious freedoms (data 62)

And we all salute the same great American flag (data 63)

The utterances above appeared in Donald Trump's victory and inauguration speeches. Those utterances represent the idea of equality delivered by using relational and material process. As in the victory speech, Trump used relational process to assign that a movement was for all American people without any exceptional races, religions, backgrounds, and beliefs. As in the inauguration speech he described that although they came from black or brown or white, they were equal to bleed the same red blood of patriots, enjoy the same 
glorious freedoms, and salute the same great American flag. From that explanation, we know that all of the concepts of equality were encoded by using relational process and was supported by material process. This means that Trump was not only talking about equality, but he also planned some actions to apply the equality for American people. Moreover, the concepts of equality existed in all of his speeches, both before and after being elected as a president, showed his consistency and strong intention in constructing this concept.

\section{c.) Citizen Involvement}

Citizens are the determinant of a nation. Every decision is made based on them. They also have full right to participate in governing a nation. As a good national leader, Donald Trump tries to bring the American people to take a part in every decision and action regarding national establishment. Trump believes that by involving the citizen of America, they will support the vision and mission which are going to be realized for his future government. This way is also used to create a condition in which the government and its society engage national affairs jointly. The concepts of citizen involvement were implicitly stated in his campaign speech in Charlotte. The quotations are as follows:

Tonight, I'd like to talk about the New American Future we are going to create together (data 64) Together, We Will Make America Strong Again (data 9)

In the quotations above, Trump used material processes to show the actions of creating new American future and making America strong again. The involvement of the citizens is reflected through adverb "together" that follows his material clauses. The word "together" implies that the actions are not only done by Trump himself, but he also invited American people to do the action with him. This is used by Trump to create more power in establishing America since the mission will be done together. Another concept of citizen involvement was also constructed in his inauguration speech after being elected as a president. The utterances are as follows:

Together, we will determine the course of America and the world for many, many years to come (data 17)

January 20, 2017, will be remembered as the day the people became the rulers of this nation again (data 34)

Together, we will make America strong again (data 23)

And yes, together, we will make America great again (data 24)

Those utterances contain the concepts of citizen involvement which are delivered through various kinds of transitivity processes. As in material clauses, by stating the word "together" Trump represents his future actions which involve the American people. He also used mental clauses to instill public mindset that the citizens would be involved in governing the country 
since he defined that American people were the rulers of the nation. In this case, the concepts of citizen involvement are mostly reflected through the word "together". The word "together" indicates that any kinds of national establishment are not only done by Trump himself, but there is also an engagement of the citizens. He continuously uttered the word "together" in his speeches. It is viewed as the unique technique used by Trump as the speaker that he implicitly constructs the concept of citizen involvement through simple code. Futhermore, it is the evidence that Donald Trump is consistent about his concept of equality because this concept is not only delivered in the campaign speech or before becoming a president but also after becoming a president.

\section{d.) National Priority}

The country actually exists to serve its citizen. Therefore, the citizens should be the first priority in every national development. This is the concept which Donald Trump was trying to build in his future government. He shared an overview to the public that he would lead the country based on American needs instead of certain people or even his own business. This idea was signaled through transitivity processes which appeared in some utterances during his speeches. As the first example, this idea was delivered in his campaign speech as in the following quotations:

We are going to put the American people first again (data 4)

I will never put anyone's interests ahead of yours (data 5)

I will never put personal profit before national security (data 7)

I will never put the special interests before the national interest (data 8)

Those statements imply that Donald Trump tries to establish the idea of national priority in his speech. He used material processes to encode his ideas. By using material process, he showed that he would give priority to American people regarding his future actions. As he said that he would put American people first again, the word "first" in his utterance indicates that American people are placed on the top as priority. In addition, he also uttered some statements which imply that he would always place national interests as the prime importance. The purpose of giving this concept in the campaign speech is as persuasive technique to attract people attention so that the American people choose and support him in president election. Then, he also delivered his concepts in some of his speeches after being elected as the president. The utterances are given below:

that while we will always put America's interests first, we will deal fairly with everyone (data 16) From this day forward, it's going to be only America first, America first (data 53)

Every decision on trade, on taxes, on immigration, on foreign affairs will be made to benefit American workers and American families (data 22) 
The utterances above are delivered in victory and inauguration speeches. Trump once again applied material process to indicate his future actions intended to establish national priority. He also used relational process to identify that for the day forward there would be American priority. It is indicated by his slogan stated "America first, America first". The use of slogan "America first" in the inauguration speech becomes his strategy to strengthen the concepts of national priority which had been constructed in his two previous speeches. From the three speeches, it can be seen that the word "first" always appears in his utterances which is associated with the concept of national priority. Thus, the word "first" is the signal for national priority.

\subsubsection{Explanation Stage}

Explanation stage is conducted to explain the ideology as the final result of this research. The concepts that have been found from interpretation are considered as the components which reveal the ideology of Donald Trump's speeches. By considering these various concepts, it can be revealed that Donald Trump tends to construct democracy view during his speeches. This is derived from what Sargent (1981: 30-31) states that democracy is an ideology which considers some principles such as citizen involvement in political decision making, some degree of equality among citizens, some degree of freedom and liberty, a system of representation, and an electoral system. Regarding this definition, two of democracy principles linguistically contain in the speeches, they are citizen involvement and equality. Whereas the other democracy principles implicitly work within these two principles. Then, the themes of national unity and national priority which do not contain in the principles are used to support and strengthen the other themes contained in the principles. In other words, the themes of national unity and national priority were also counted in the democracy principles.

\section{CONCLUSION}

In the beginning of 2017, Donald Trump was the most central world discussion since he won the $45^{\text {th }}$ presidential election in the United States. In this case, he replaced Barack Obama as the previous president of America. Barack Obama had successfully reigned America for two periods of government and had so many supporters during his leadership. As the next elected president, Donald Trump certaintly has something interesting in his speeches to attract American people to choose him to be the next national leader of America. This present research has discussed the linguistics features of Donald Trump's speeches, which eventually reveal the linguistic strategies as well as its ideological construction. By using an interesting 
combination of critical disourse study with the new perspective of grammar theory, the writer has proven that transitivity system is truly capable to reveal the ideology from the speeches. Moreover, this study shows how Donald Trump as the $45^{\text {th }}$ president of United States uses his languange to share his political ideology during his speeches. The use of variety language and a strong consistency in maintaining the concepts for his future actions are considered as the persuasive strategy to convince the public so that the American people support him in the future government.

\section{REFERENCES}

Al-Haq, F.A. \& Al-Sleibi, N.M. (2015). A Critical Discourse Analysis of Three Speeches of King Abdullah II. US-China Foreign Language, 13(5), 317-332.

Anggun, S.K. (2016). An Analysis of Description Text in English Textbook UsingTransitivity System. Journal of English and Education, 4(1), 147-158.

Ary, D., Jacobs, L.C., \& Sorensen, C. (2010). Introduction to Research in Education. Canada: Wadsworth.

Aslani, M. (2016). Ideological Traces in Political Texts: A CDA Approach Towards News Representation and Translation of Iran's Nuclear Program in English and Persian Written Media. International Journal of Applied \& English Literature, 5(3), 237-246.

Fairclough, N. (1989). Language and Power. New York: Longman Group.

Fauzan, U. (2014). A CDA of The Ideology of Indonesian TVOne News Report. JurnalIlmiah Bahasa dan Sastra, 1(2), 211-229.

Fikmawati. (2012). An Analysis of Speech Function in the Script of Confession of a Shopaholic Movie By P.J. Hogan. (Thesis, Muria Kudus University).

Halliday, M.A.K. (1985). An Introduction to Functional Grammar. London: Edward Arnold.

Halliday, M.A.K. \& Webster, J. J. (2009). Systemic Functional Linguistics. London:Continuum Companion Publishing Group.

Kaur, K., Arumugam, N., \& Yunus, N.M. (2013). Beauty Product Advertisements: A Critical Discourse Analysis. Asian Social Science, 9(3), 61-71.

Khoiriyah, L. (2016). Beauty Concept in Toothpaste Advertisement: A Critical Discourse Analysis. (Thesis, UIN Maulana Malik Ibrahim).

Kurdali, B. (2012). Systemic Functional Analysis of EFL University Students' Writing Across Disciplines. International Journal of Law and Social Sciences, 2(1), 289-295.

Litosseliti, L. (2010). Research Method in Linguistics. New York: Continuum International Publishing Group. 
Mohammadi, M. (2017). A Critical Discourse Analysis of Donald Trump's Language Use in US Presidential Campaign, 2016. International Journal of Applied Linguistics \& English Literature, 6(5), 1-10.

Nazlia. (2016). An Analysis of Transitivity Process and The Schematic Structure of News Item in Selected News of VOA News. (Thesis, Sumatra Utara University).

Nugrawidhanti, D.M.R. (2016). A Critical Discourse Analysis on Oriflame Beauty Product Advertisements. (Thesis, Sanata Dharma University).

Nurohmah, I. (2013). An Analysis of Student's Recount Text by Using Systemic Functional Grammar. Passage, 1(2), 89-98.

Oliviera, L.C. (2015). A Systemic-Functional Analysis of English Language Learners' Writing. (Thesis, University of Miami).

Ong'onda, N.A. (2016). Transitivity Analysis of Newspaper Headlines on Terrorism Attackin Kenya: A Case Study of Westgate Mall, Nairobi. International Journal of Humanities and Social Science, 6(7), 59-70.

Oriza, F.R. (2017). The Depiction of Islamic Princess in Children's Books: A Transitivity Analysis. (Thesis, Universtitas Muhammadiyah Surakarta).

Paltridge, B. (2006). Discourse Analysis. London: Continuum.

Patpong, P.J. (2008). Language of Persuasion: An Analysis of Selected Samples from Talisman Advertisements. Odense Working Papers in Language and Communication, 29, 633-664.

Rollins, A.J. (2012). Systemic Functional Linguistic Discourse Features in the Personal Essay. (Thesis, Marshall University).

Salsabil, Silvi. (2014). A Transitivity Analysis of English Texts in Bahasa Inggris When English Ring the Bell. (Thesis, Yogyakarta State University).

Sargent, L.T. (1981). Contemporary Political Ideology. Illinois: The Dorsey Press.

Setiawan, W. (2015). An Analysis of Speech Function on Monsters University Movie Script By Dan Scanlon, Daniel Gerson, and Robert L. Baird. (Thesis, Muria Kudus University).

Sipra, M.A. \& Rashid, A. (2013). Critical Discourse Analysis of Martin Luther King's Speech in Socio-Political Perspective. Advances in Language and Literary Studies, 4(1), 27-33.

Viana, T.N. (2013). Mood and Speech Function in "Toy Story 3” Movie Script by Michael Arndt. (Thesis, Muria Kudus University).

Viscido, Francesca. (2014). Any Port in a Storm: A Systemic Functional Analysis of Linguistic Choices of Representation in News Text. (Thesis, University of Tampere).

Wodak, R. \& Meyer, M. (2001). Method of Critical Discourse Analysis. London: SAGE Publications.

Zhang, X. (2013). The Third U.S. -China Strategic and Economic Dialogue: A Contrastive Study of Chinese and American Newspaper News Reporting. (Thesis, University of Florida). 
Zhang, Y. (2017). Transitivity Analysis of Hillary Clinton's and Donald Trump's First Television Debate. International Journal of Applied Linguistics \& English Literature, 6(7), 65-72.

https://www.politico.com/story/2016/08/donald-trump-never-lie-227183

https://edition.cnn.com/2016/11/09/politics/donald-trump-victory-speech/index.html

https://edition.cnn.com/2017/01/20/politics/trump-inaugural-address/index.html 